\title{
DATING OF GROUNDWATER RECHARGE IN TWO SMALL ADJACENT AQUIFERS IN ISRAEL AND THEIR INITIAL ${ }^{14} \mathrm{C}$ ACTIVITIES
}

\author{
$\mathrm{J} \mathrm{Guttman}^{1} \cdot \mathrm{J} \mathrm{Kronfeld}^{2} \cdot \mathrm{I} \mathrm{Carmi}^{3,4}$
}

\begin{abstract}
Radiocarbon and tritium determinations were carried out in 2 adjacent small aquifers in Israel. These aquifers have small storage capacities and good hydraulic properties. Darcy calculations suggest that the aquifers contain young waters, $\sim 50 \mathrm{yr}$ in age. ${ }^{14} \mathrm{C}$ concentrations in the Pleistocene aquifer are between 23-60 pMC, with the lowest activity related to contamination by petroleum-based fertilizers with no ${ }^{14} \mathrm{C} .{ }^{14} \mathrm{C}$ concentrations in the Judea Group aquifer range from 62 to $95 \mathrm{pMC}$. An apparent difference of $\sim 1000 \mathrm{yr}$ is indicated for the average recharge age between the 2 aquifers. The tritium data suggests that the water in both aquifers is quite young. The 1000 -yr difference is an artifact of initial isotopic fractionation differences through the unsaturated zone as established elsewhere for these 2 aquifers. When these individual fractionation factors ( 0.54 for the Pleistocene and 0.62 for the Judea Group) are used, it is revealed that both aquifers contain young water, in agreement with the Darcy calculation, which was recharged at the beginning of the period of thermonuclear atmospheric testing in the early 1960s.
\end{abstract}

\section{INTRODUCTION}

Water is a scarce and important commodity in Israel, where rainfall is restricted to the winter season. The use of groundwater is necessary in order to augment the water supply at other times of the year. For this, understanding the age of water in aquifers is of major importance. This paper reports research on this problem in the Judea Group and Pleistocene aquifers in the Taninim region of Israel.

\section{Hydrogeology Background}

Along the northern Mediterranean coast of Israel, there are 2 juxtaposed aquifers, the Judea Group carbonate aquifer of Mount Carmel, which is unconfined to the east and confined to the west under the second aquifer, the Pleistocene sandy aquifer, situated parallel to the coast (Figure 1). The sands and soils above the Pleistocene aquifer are intensively used for fish-farming and agriculture.

Natural replenishment to these aquifers is predominantly by rain falling over their unconfined portions. The direction of flow depends upon the relative water levels in each aquifer. These water levels in both aquifers are higher eastward, and in the Judea Group aquifer they are higher than in the Pleistocene aquifer. Thus, the flow is naturally from east to west. At Mount Carmel, several springs, notably En Alon and En Kedem (Figure 3, sites 16 and 17, respectively), issue forth from the carbonate aquifer. No springs issue forth from the Pleistocene aquifer. The major Taninim springs (Figure 3, sites 20 and 21) are predominately drainage from the Judea Group aquifer, as will be discussed later. Along the lithologic contacts there exist fensters, which enable an hydraulic interconnection between the 2 aquifers (Figure 2).

The Pleistocene aquifer has, in addition to rainfall, several input sources, which has made it increasingly salty. These include leakage from the fishponds, recycling of irrigation water, and sea spray. All of the exploitation wells in the Judea aquifer are restricted to the unconfined section. During the summer, large-scale pumping lowers the static water levels below that of the levels in the Pleistocene aquifer. This may allow for groundwater flow eastwards from the Pleistocene aquifer into portions of the Judea Group aquifer via the fensters.

\footnotetext{
${ }^{1}$ Mekorot Israel National Water Co., PO Box 2012, 61201 Tel Aviv, Israel.

${ }^{2}$ Department of Geophysics and Planetary Science, Tel Aviv University, PO Box 39040, 69978 Tel Aviv, Israel.

${ }^{3}$ Department of Environmental Science and Energy Research, Weizmann Institute of Science, PO Box 26, 76100 Rehovot, Israel. Present address: Department of Geophysics and Planetary Science, Tel Aviv University, PO Box 39040, 69978 Tel Aviv, Israel. Corresponding author. Email: carmiisr@post.tau.ac.il.
} 


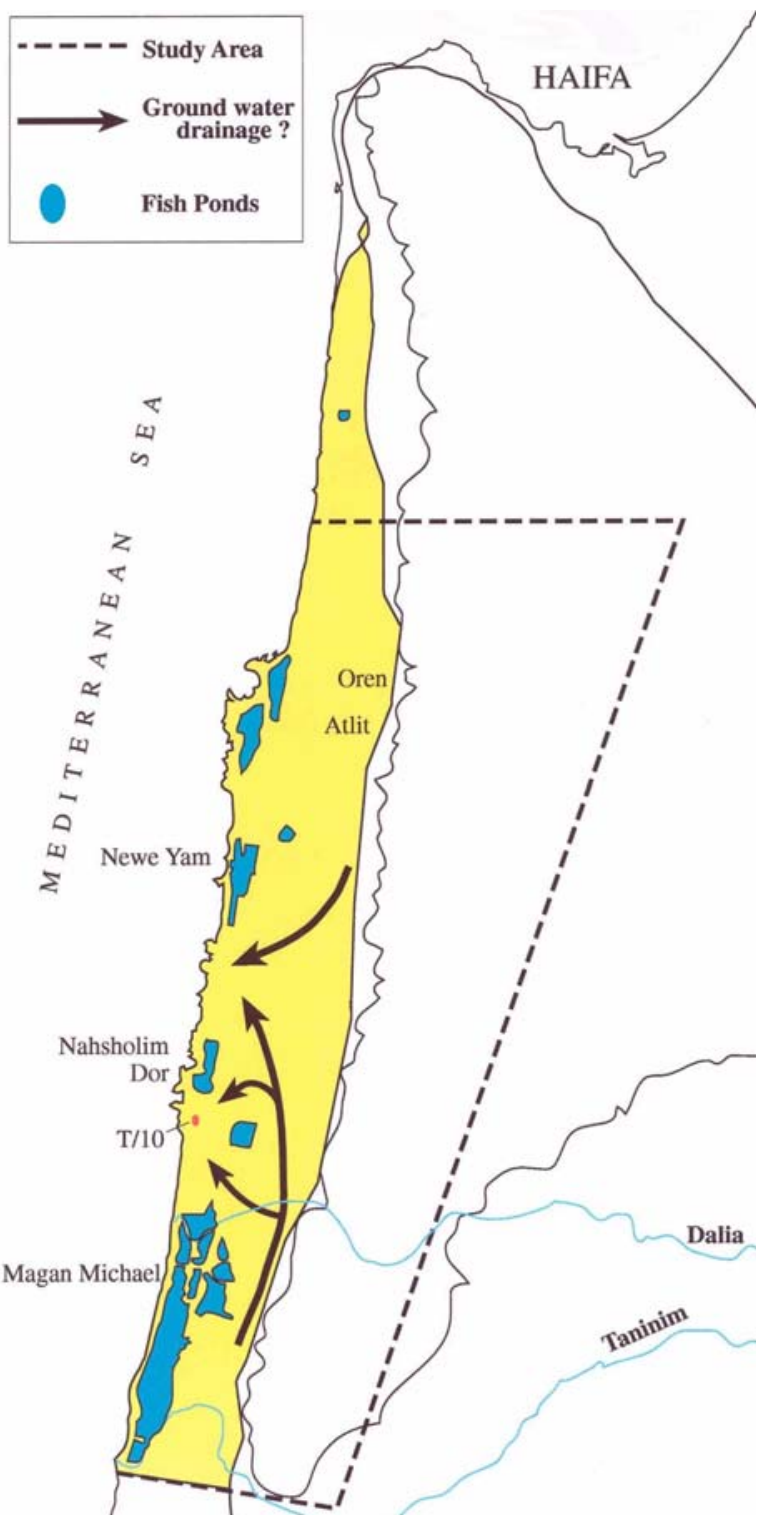

Figure 1 Location map

\section{Ages of the Water in the Aquifers: Problems and a Solution}

To estimate the age and rate of flow of groundwater, which is necessary for the optimal exploitation, radiocarbon and tritium as well as conventional Darcy flow models were employed. However, when the results came in an apparent discrepancy was noted both between the ages and rates of flow estimated by these methods, as well as an apparent age difference of $1000{ }^{14} \mathrm{C}$ yr, which from a hydrological perspective seemed improbable. However, recent carbon isotopic studies of these 2 aquifer units to the south of the present study area (Carmi 2007; Carmi et al. 2004, 2009) enable both apparent age discrepancies in the Carmel coastal region to be resolved adequately. 


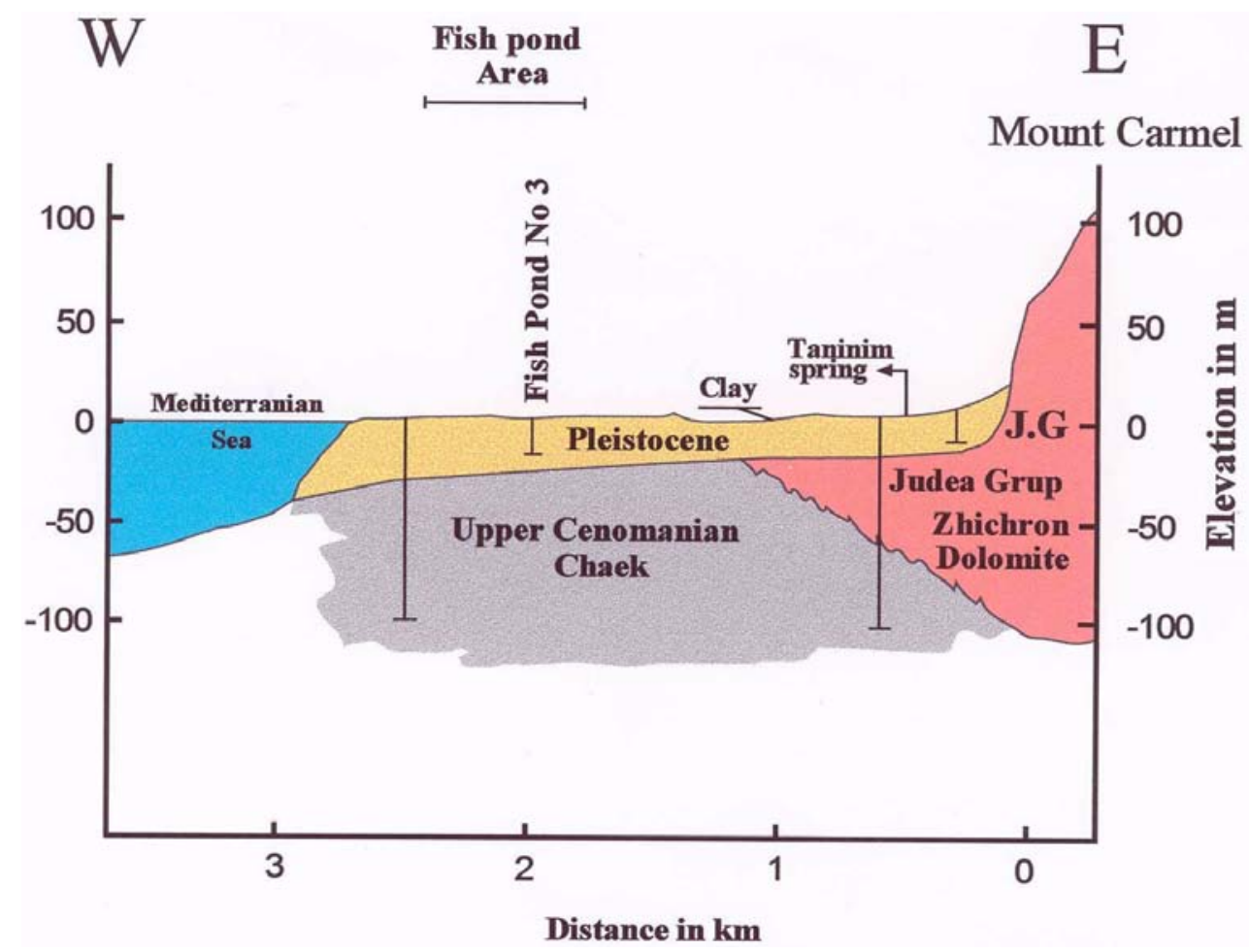

Figure 2 Geological cross-section of the Carmel coast showing the Pleistocene and Judea Group aquifers with possible interconnections.

\section{METHODS}

Samples of representative wells from both aquifers were collected between 1991 and 1995 from producing wells, fishponds, and 2 springs (Figure 3). Forty-liter samples of water for ${ }^{14} \mathrm{C}$ and $\delta^{13} \mathrm{C}$ analyses and 1-L samples of water for tritium analyses were taken from the wells, springs, and fishponds. Wells had been operating for at least $2 \mathrm{hr}$ before sampling. Several tritium samples of rainfall were collected as well during the study. The 1-L samples were collected in glass bottles and 40-L samples were collected in Nalgene ${ }^{\circledR}$ drums. Water filled the entire volume, ensuring that no air pockets remained in either sampling collections.

Water samples were transferred to the Weizmann Institute of Science in Rehovot, where they were processed immediately and analyzed for ${ }^{14} \mathrm{C}, \delta^{13} \mathrm{C}$, tritium, $\delta^{18} \mathrm{O}$, and $\delta \mathrm{D} .{ }^{14} \mathrm{C}$ measurements were carried out on the $\mathrm{CO}_{2}$ that was extracted from the groundwater, which was converted to ethane and measured in gas proportional counters. Tritium analyses were performed after the tritium was enriched by electrolysis and converted to ethane and measured likewise. The results of the ${ }^{14} \mathrm{C}$ analyses are expressed in percent with respect to modern carbon (pMC), with the associated statistical counting error at the $1-\sigma$ level of confidence. The stable isotopes of ${ }^{13} \mathrm{C},{ }^{2} \mathrm{H}$, and ${ }^{18} \mathrm{O}$ were measured in an Atlas MAT 250 mass spectrometer. $\delta^{13} \mathrm{C}$ values of the total dissolved inorganic carbon are reported relative to the PDB standard (Craig 1953), with a precision of $0.2 \%$, unless otherwise noted. The tritium concentrations are reported in tritium units $\left(1 \mathrm{TU}=1\right.$ atom tritium per $10^{18}$ atoms of hydrogen). The associated standard deviation is reported at the $1-\sigma$ level of confidence. The detection limit of tritium is, for all practical purposes, $<1$ TU. $\delta^{18} \mathrm{O}$ and $\delta \mathrm{D}$ are reported relative to SMOW (Coplen 1996) with respective precisions of $0.2 \%$ and $2 \%$. 


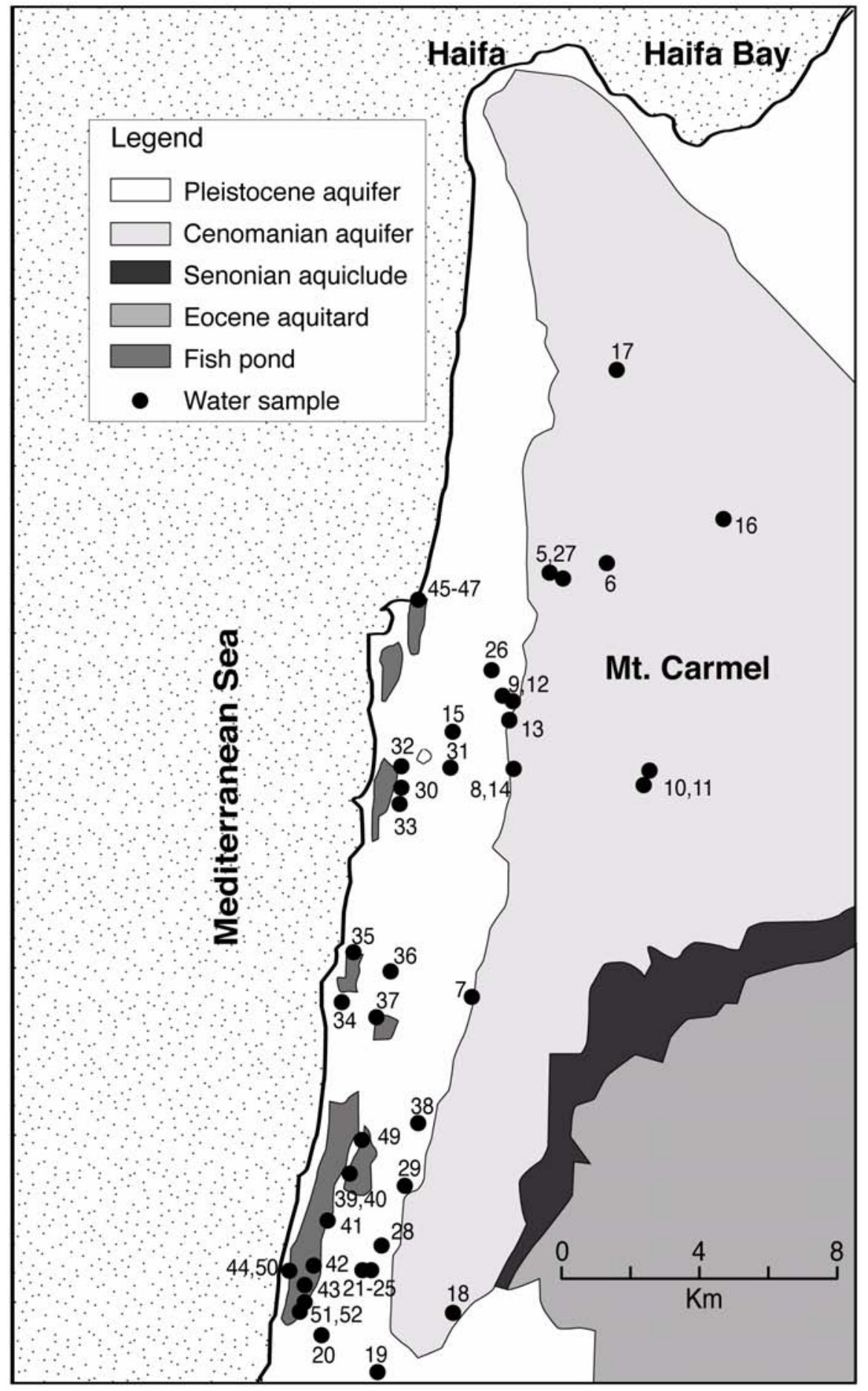

Figure 3 Map of the sampling sites (see Tables 2 and 3 for details) 


\section{RESULTS}

The tritium results in rains are reported in Table 1. They fall in a range from 3.2 to 4.9 TU. In Israel, generally the tritium value in rainfall in the $2 \mathrm{yr}$ of sampling was $\sim 4.5 \mathrm{TU}$. Table 2 presents the data for the Judea Group Aquifer and Table 3 presents the same data for the Pleistocene Aquifer. It had been shown previously by the WATEQ4F (Ball and Nordstrom 1992) protocol that in each case the water is saturated with respect to the carbonate minerals and greatly undersaturated with respect to the common chloride and sulfate minerals (Guttman 1999).

Table 1 Tritium in western Carmel, Haifa rain.

\begin{tabular}{lll}
\hline Sample & Date & TU \\
\hline 4d & 8 Nov 94 & $4.9 \pm 0.2$ \\
4e & 15 Nov 94 & $3.4 \pm 0.2$ \\
4f & 1 Dec 94 & $3.2 \pm 0.2$ \\
4g & 31 Dec 94 & $4.0 \pm 0.3$ \\
4h & 18 Jan 95 & $3.5 \pm 0.2$ \\
4I & 8 Feb 95 & $3.7 \pm 0.2$ \\
\hline
\end{tabular}

\section{DISCUSSION}

\section{Darcy Age of the Water and Rates of Flow}

Before radiometric determinations are carried out, an estimation of the flow rate would ordinarily be made by use of Darcy's Law, written as $v=-K \Delta h / \Delta l$, where $v$ is the velocity of flow, $K$ is the hydraulic conductivity, $\Delta h$ is the difference in water levels between 2 wells, and $\Delta l$ is the distance between them.

In both aquifers, the static hydrological situation has been highly disturbed by pumping during the summer months. As noted previously, this can result in a reversal of flow gradients. In the Judea Group, which has a relatively small storage capacity, the exploitation during the summer can cause static water levels to fall below those of the Pleistocene aquifer. It is therefore not relevant to attempt to estimate flow rates based on data obtained during the summer. During the winter, with the cessation of the exploitation and the addition of the winter recharge, the situation reverts to one more clearly in line with what may have existed before pumping. Average flow velocities were calculated using static water levels from the winter in an east-west profile from Nahal Oren 5 to Nahal Oren 3 (Figure 4) $(\Delta l=1.3 \mathrm{~km})$ and from Nahal Oren 3 to Atlit 1 (Figure 4$)(\Delta l=1.3 \mathrm{~km})$. During the winter of 1970 , the water levels stood at $+7.24,+5.76$, and $+4.35 \mathrm{~m}$, respectively. The hydraulic conductivity of the Judea Group is generally within the range of 100-200 m/day. The velocity of groundwater from the Darcy equation ranges from 42 to $83 \mathrm{~m} / \mathrm{yr}$ from Nahal Oren 5 to Nahal Oren 3 and from 40 to $79 \mathrm{~m} / \mathrm{yr}$ from Nahal Oren 3 to Atlit 1 . At an average velocity of $60 \mathrm{~m} / \mathrm{yr}$, it should take no more than $50 \mathrm{yr}$ for the water to transverse a distance of $\sim 3 \mathrm{~km}$. Thus, the average age of the water in the unconfined part of the Judea Group aquifer should be less than $50 \mathrm{yr}$.

A similar determination of the velocity of groundwater movement is more problematic for the Pleistocene aquifer. Since the fishponds were built, the westernmost water levels exhibited in the wells near the fishponds have been standing higher than the water levels measured in the Pleistocene aquifer wells to the east of the fishponds. This is due to leakage from the ponds and holds true generally both for winter and summer seasons. During exceptionally rainy winters, the wells to the east may attain higher water levels and permit a direct flow from east to west across the aquifer. At other 
Table 2 Isotope data of the water in the Judea Group aquifer.

\begin{tabular}{|c|c|c|c|c|c|c|c|c|}
\hline Code & Site & $\begin{array}{l}\text { Well depth } \\
\text { (m) }\end{array}$ & $\begin{array}{l}\text { Date } \\
(\mathrm{d} / \mathrm{m} / \mathrm{yr})\end{array}$ & $\begin{array}{l}\delta \mathrm{D} \\
(\%)\end{array}$ & $\begin{array}{l}\delta^{18} \mathrm{O} \\
(\%)\end{array}$ & $\begin{array}{l}\text { Tritium } \\
\text { (TU) }\end{array}$ & $\begin{array}{l}\delta^{13} \mathrm{C} \\
(\% \text { ) }\end{array}$ & $\begin{array}{l}{ }^{14} \mathrm{C} \\
(\mathrm{pMC})\end{array}$ \\
\hline 5 & Nahal Oren 1 & 117.7 & $21 / 8 / 91$ & -23 & -5.4 & & & \\
\hline $5 b$ & Nahal Oren 1 & 117.7 & $30 / 6 / 93$ & & -5.6 & & & \\
\hline $5 c$ & Nahal Oren 1 & 117.7 & $21 / 6 / 94$ & & -5.5 & $4.0 \pm 0.3$ & -11.1 & $69.7 \pm 0.5$ \\
\hline $5 d$ & Nahal Oren 1 & 117.7 & $1 / 6 / 95$ & -26 & -5.5 & & & \\
\hline 6 & Nahal Oren 5 & 139.7 & 21/8/91 & -24 & & & -11.1 & \\
\hline $6 a$ & Nahal Oren 5 & 139.7 & $21 / 8 / 94$ & & -5.4 & & & \\
\hline $6 b$ & Nahal Oren 5 & 139.7 & $8 / 6 / 95$ & & & $5.1 \pm 0.2$ & -10.2 & $66.7 \pm 0.3$ \\
\hline 7 & Hof Carmel 2 & 37.5 & 21/8/91 & -20 & -4.8 & & -11.1 & \\
\hline 8 & Hof Carmel 4 & 50.5 & $9 / 1 / 94$ & -23 & -4.7 & & & \\
\hline $8 a$ & Hof Carmel 4 & 50.5 & 6/9/94 & & -4.8 & & & \\
\hline $8 b$ & Hof Carmel 4 & 50.5 & $15 / 4 / 95$ & & -4.7 & $2.2 \pm 0.2$ & -11.0 & $71.1 \pm 0.4$ \\
\hline 9 & Hof Carmel 6 & 47 & 21/8/91 & -23 & -5.1 & & & \\
\hline 9a & Hof Carmel 6 & 47 & 25/11/91 & -27 & -5.4 & $2.7 \pm 0.2$ & & \\
\hline $9 b$ & Hof Carmel 6 & 47 & $20 / 4 / 92$ & & -5.4 & & & \\
\hline $9 c$ & Hof Carmel 6 & 47 & 3/8/92 & -29 & -5.2 & $<2.5$ & & \\
\hline $9 d$ & Hof Carmel 6 & 47 & $30 / 6 / 93$ & & -5.5 & & -10.3 & \\
\hline $9 e$ & Hof Carmel 6 & 47 & $21 / 6 / 94$ & & -5.5 & $2.4 \pm 0.3$ & & \\
\hline 9f & Hof Carmel 6 & 47 & 6/9/94 & & -5.4 & & & \\
\hline $9 g$ & Hof Carmel 6 & 47 & $11 / 7 / 94$ & & & $1.8 \pm 0.2$ & -11.4 & \\
\hline 10 & Hof Carmel 7 & 155 & $21 / 8 / 91$ & -22 & -4.9 & & & \\
\hline $10 \mathrm{~b}$ & Hof Carmel 7 & 155 & $6 / 9 / 94$ & & -4.7 & & & \\
\hline $10 \mathrm{c}$ & Hof Carmel 7 & 155 & $1 / 6 / 95$ & -23 & -5.0 & $2.2 \pm 0.2$ & -11.1 & $64.9 \pm 0.4$ \\
\hline 11 & Hof Carmel 9 & 175 & $6 / 9 / 94$ & & -5.2 & & & \\
\hline 12 & El Mazar 1 & 37.5 & 21/8/91 & & -5.2 & & & \\
\hline $12 \mathrm{a}$ & El Mazar 1 & 37.5 & $1 / 6 / 95$ & -23 & -5.4 & $2.6 \pm 0.2$ & -10.1 & \\
\hline 13 & El Mazar 2 & 62.4 & $6 / 9 / 94$ & & -5.4 & & & \\
\hline 14 & Nahal Me'ara 1 & 86.9 & 21/8/91 & -22 & -5.1 & & & \\
\hline $14 a$ & Nahal Me'ara 1 & 86.9 & $6 / 4 / 93$ & & -5.2 & & & \\
\hline $14 \mathrm{~b}$ & Nahal Me'ara 1 & 86.9 & $30 / 6 / 93$ & & -5.3 & & -11.2 & \\
\hline 15 & En Hayam 1 & 128.8 & 21/8/91 & -20 & -4.4 & & -12.3 & \\
\hline $15 \mathrm{a}$ & En Hayam 1 & 128.8 & $30 / 6 / 93$ & & -4.7 & & -10.6 & \\
\hline $15 b$ & En Hayam 1 & 128.8 & $21 / 6 / 94$ & -22 & -4.5 & & & \\
\hline 16 & En Alon spring & 1 & 20/4/92 & & -5.2 & & -12.8 & \\
\hline $16 a$ & En Alon spring & 1 & $15 / 4 / 95$ & & & $6.8 \pm 0.2$ & -12.2 & $95.5 \pm 0.6$ \\
\hline 17 & En Kedem spring & 1 & $11 / 2 / 95$ & -27 & -5.6 & & -12.8 & \\
\hline 18 & Shoni 3 90m & 100.5 & 18/4/93 & & -4.9 & & & \\
\hline $18 \mathrm{a}$ & Shoni 3 90m & 100.5 & $12 / 1 / 0 / 94$ & & -4.7 & & -9.8 & \\
\hline 19 & Binyamina $1^{\mathrm{a}}$ & 56.4 & $11 / 1 / 0 / 94$ & & -4.3 & & & \\
\hline 20 & Taninim T/3 30m & 36.8 & $18 / 4 / 93$ & & -4.7 & & & \\
\hline 21 & Taninim $\mathrm{T} / 5^{1}$ shallow & 11.9 & $12 / 10 / 94$ & -24 & -4.9 & & -8.3 & \\
\hline 22 & Taninim T/51 deep & 25.3 & $18 / 4 / 94$ & & -4.2 & & & \\
\hline $22 \mathrm{a}$ & Taninim T/5¹ deep & 25.3 & $12 / 10 / 94$ & & -4.9 & & -9.8 & \\
\hline 23 & Taninim spring $29^{\mathrm{b}}$ & 1 & $15 / 12 / 90$ & & & $1.5 \pm 0.2$ & & \\
\hline $23 a$ & Taninim spring 29 & 1 & $18 / 4 / 93$ & & -4.7 & $<1.6$ & -11.0 & \\
\hline $23 b$ & Taninim spring 29 & 1 & $18 / 4 / 94$ & -21 & -4.7 & & -13.1 & \\
\hline $23 c$ & Taninim spring 29 & 1 & $12 / 10 / 94$ & -22 & -4.7 & & -10.3 & \\
\hline 23d & Taninim spring 29 & 1 & 21/6/94 & & & $1.3 \pm 0.1$ & & $62.2 \pm 0.4$ \\
\hline 24 & Taninim spring 36 & 1 & $18 / 4 / 93$ & -19 & -4.4 & $<1.3$ & & \\
\hline 25 & Taninim spring 49 & 1 & $18 / 4 / 93$ & & -4.7 & & & \\
\hline 26 & Atlit council & 61.3 & $20 / 8 / 95$ & & & $3.1 \pm 0.2$ & -13.0 & $65.4 \pm 0.4$ \\
\hline
\end{tabular}

a Sample taken $1 \mathrm{~m}$ below static water level.

bThe Taninim spring complex outlet flows through the Pleistocene sequence, though it is believed to drain the Judea Group aquifer. 
Table 3 Isotope data of the water in the Pleistocene aquifer.

\begin{tabular}{|c|c|c|c|c|c|c|c|c|}
\hline Code & Site & $\begin{array}{l}\text { Well depth } \\
\text { (m) }\end{array}$ & $\begin{array}{l}\text { Date } \\
(\mathrm{d} / \mathrm{m} / \mathrm{yr})\end{array}$ & $\begin{array}{l}\delta \mathrm{D} \\
\text { (\%o) }\end{array}$ & $\begin{array}{l}\delta^{18} \mathrm{O} \\
(\%)\end{array}$ & $\begin{array}{l}\text { Tritium } \\
\text { (TU) }\end{array}$ & $\begin{array}{l}\delta^{13} \mathrm{C} \\
(\%)\end{array}$ & $\begin{array}{l}{ }^{14} \mathrm{C} \\
(\mathrm{pMC})\end{array}$ \\
\hline 30 & Newe Yam 2 & 25 & $25 / 11 / 91$ & -18 & -3.3 & $3.0 \pm 0.2$ & -7.9 & \\
\hline 31 & Newe Yam 3 & 32.3 & 25/11/91 & -23 & -4.2 & $3.2 \pm 0.2$ & -9.3 & \\
\hline $31 \mathrm{a}$ & Newe Yam 3 & 32.3 & 21/6/94 & -20 & -4.5 & $1.8 \pm 0.3$ & & \\
\hline $31 b$ & Newe Yam 3 & 32.3 & 11/8/95 & -25 & & $2.8 \pm 0.2$ & -11.8 & $53.2 \pm 0.3$ \\
\hline 33 & Newe Yam 5 & 22 & $25 / 11 / 91$ & $-33(?)$ & -4.5 & $3.0 \pm 0.2$ & -8.5 & \\
\hline 33a & Newe Yam 5 & 22 & 30/6/93 & & -4.4 & & & \\
\hline $33 b$ & Newe Yam 5 & 22 & $20 / 8 / 95$ & & & $2.4 \pm 0.2$ & -9.2 & $54.9 \pm 0.3$ \\
\hline 34 & Nachsholim A & 22.6 & $25 / 11 / 91$ & -19 & -3.9 & $2.7 \pm 0.2$ & & \\
\hline 35 & Nachsholim B & 30 & $25 / 11 / 91$ & -14 & -2.4 & $5.0 \pm 0.5$ & -5.0 & \\
\hline $35 a$ & Nachsholim B & 30 & $3 / 8 / 92$ & -13 & -2.2 & $3.9 \pm 0.6$ & -7.4 & \\
\hline $35 b$ & Nachsholim B & 30 & $21 / 6 / 94$ & & -2.2 & $4.4 \pm 0.3$ & & \\
\hline 36 & Nachsholim C & 20.8 & $25 / 11 / 91$ & -23 & -4.7 & $5.6 \pm 0.3$ & & \\
\hline $36 a$ & Nachsholim C & 20.8 & 30/6/93 & & -5.0 & & -9.6 & \\
\hline $36 b$ & Nachsholim C & 20.8 & $21 / 6 / 94$ & -22 & -5.0 & $2.8 \pm 0.3$ & -11.0 & $23.3 \pm 0.3$ \\
\hline $36 c$ & Nachsholim C & 20.8 & $1 / 6 / 95$ & -22 & -4.9 & $2.4 \pm 0.2$ & -5.9 & $49.3 \pm 0.5$ \\
\hline 37 & Dor A & 24.9 & $3 / 8 / 92$ & -19 & -3.8 & $<1.5$ & -7.7 & \\
\hline 38 & Shfeya A & 23.2 & $30 / 6 / 93$ & & -4.9 & & -10.7 & \\
\hline $38 a$ & Shfeya A & 23.2 & 8/6/95 & -22 & -5.0 & $4.9 \pm 0.2$ & -10.8 & $61.7 \pm 0.4$ \\
\hline 39 & Maayan Zvi M-2a & 33 & $30 / 6 / 93$ & & -1.8 & & -6.5 & \\
\hline $39 a$ & Maayan Zvi M-21 & 33 & $21 / 6 / 94$ & -9 & -2.3 & & -7.1 & \\
\hline $39 b$ & Maayan Zvi M-2 1 & 33 & $11 / 10 / 94$ & & -3.4 & & & \\
\hline 40 & T/7 (Hof Carmel) & 16.6 & $11 / 10 / 94$ & & -2.3 & & & \\
\hline 28 & Maagan Michael Meshek & 22.5 & $12 / 10 / 94$ & -22 & -4.7 & & & \\
\hline 41 & Maagan Michael fishpond 1 & 31 & $19 / 12 / 92$ & & -4.7 & $<1.5$ & & \\
\hline 42 & Maagan Michael fishpond 3 & 21 & $1 / 6 / 95$ & -19 & -4.1 & $1.5 \pm 0.2$ & -8.9 & $59.4 \pm 0.4$ \\
\hline 43 & Maagan Michael fishpond 4 & 22 & $12 / 1 / 0 / 94$ & -19 & & & & \\
\hline 44 & Maagan Michael fishpond 13 & 38 & $18 / 4 / 93$ & & -4.2 & $3.2 \pm 0.7$ & -9.1 & \\
\hline 45 & Atlit fishpond 1 & 28 & $15 / 8 / 94$ & & -4.0 & & & \\
\hline 46 & Atlit fishpond 2 & 27 & $15 / 8 / 94$ & & -2.6 & & & \\
\hline 47 & Atlit salt pond $6 \%$ & 1 & $15 / 8 / 94$ & & +5.8 & & & \\
\hline 48 & Nachsholim fishpond & 1 & $3 / 8 / 92$ & 0 & +0.5 & $5.6 \pm 0.5$ & -8.6 & \\
\hline $48 a$ & Nachsholim fishpond & 1 & $30 / 6 / 93$ & +10 & +2.1 & & -7.0 & \\
\hline $48 b$ & Nachsholim fishpond & 1 & $30 / 6 / 94$ & & +2.2 & & & \\
\hline $48 \mathrm{c}$ & Nachsholim fishpond & 1 & $15 / 8 / 94$ & +2 & +0.1 & & -3.0 & \\
\hline 49 & Mayyan Zvi fishpond & 1 & $15 / 8 / 94$ & +9 & +2.1 & & -1.9 & \\
\hline 49a & Mayyan Zvi fishpond & 1 & $11 / 10 / 94$ & & +0.8 & & & \\
\hline 50 & Maagan Michael fishpond & 1 & $18 / 4 / 94$ & & -2.1 & & -8.4 & \\
\hline $50 \mathrm{a}$ & T/4 (Maagan Michael fishpond) ${ }^{\mathrm{b}}$ & & $11 / 1 / 0 / 94$ & -6 & -1.7 & & & \\
\hline $50 \mathrm{~b}$ & T/4 (Maagan Michael fishpond) & & $15 / 11 / 95$ & & -1.7 & & -7.7 & \\
\hline 53 & Fish food & & & & & & -15.7 & \\
\hline
\end{tabular}

a Well located in the fishpond areas.

${ }^{\mathrm{b}}$ Observation well $\mathrm{T} / 4$ is near the fishpond.

times, the only flow seawards would occur either from (1) water seeping downwards to the west of the axis of the water mound under the fishponds, or (2) in the gaps between the main fishpond areas (Figure 3). Unfortunately, the water level data for this region is very sparse. However, a rough approximation may be obtained by comparing the water levels in the Dor well $(+2.40 \mathrm{~m}$, winter of 1961) to the water level in the $T / 10$ observation well located $700 \mathrm{~m}$ from the shore $(+2.31 \mathrm{~m}$ for the same season) (Figure 4). The distance between these wells is $\sim 500 \mathrm{~m}(\Delta l=0.5 \mathrm{~km})$. The hydraulic conductivity for the Pleistocene aquifer varies between 30-400 m/day (the latter value was encountered in some wells located near the fishponds of the kibbutz Maagan Michael (Figure 3), and is 


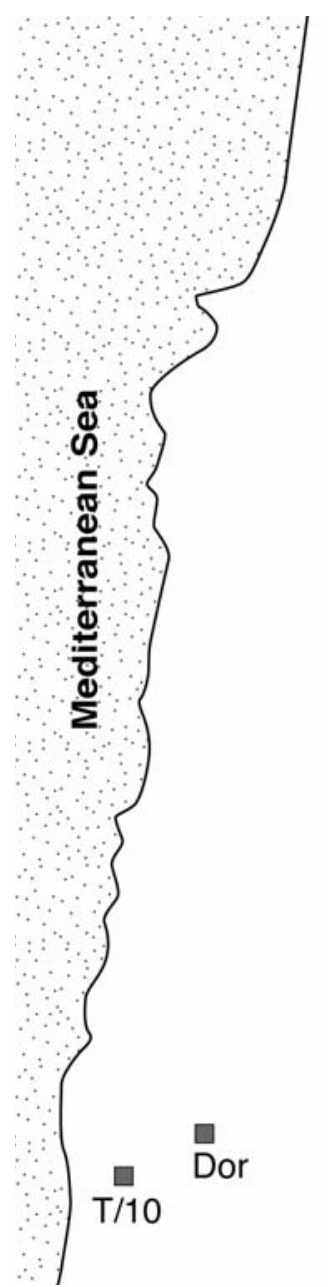

\section{N. Oren 5 \\ Atlit 1 \\ N. Oren 3}

Figure 4 Location of wells that were used for the velocity calculations by the Darcy method (see text).

exceptionally high). If an average of these 2 extremes ( $215 \mathrm{~m} /$ day) is taken for $K$, a velocity of 20 $\mathrm{m} / \mathrm{yr}$ is obtained for flow from the Dor well to the T/10 well. At this rate, it would it should take $35 \mathrm{yr}$ for the water to transverse the $700 \mathrm{~m}$ to the sea. Thus, the water today within the Pleistocene aquifer should be, on average, somewhat greater than $35 \mathrm{yr}$ old. These are very rough approximations. Therefore, the radiometric techniques for dating water, radiocarbon $\left({ }^{14} \mathrm{C}\right)$ and tritium $\left({ }^{3} \mathrm{H}\right)$, were used in an attempt to validate or refine these ages.

\section{Stable Isotopes of Water}

In the wells and springs of the Judea Group aquifer, the stable isotope data of ${ }^{2} \mathrm{H}$ and ${ }^{18} \mathrm{O}$ is quite uniform (Table 2) and are similar to the values found in this aquifer elsewhere in Israel (Kroitoru 1987). The data are plotted in a $\delta^{2} \mathrm{H}-\delta^{18} \mathrm{O}$ diagram in Figure 5 and compared to the Eastern Mediterranean Meteoric line (EML) (Gat and Dansgaard 1970). The recharge water undergoes some evaporation as the data lies beneath and to the right of the EML. In Table 2, there are 11 wells that were sampled 
more than once. Of them, two (8 and 9) were sampled both in the winter and in the summer. Their isotopes essentially do not change between the seasons.

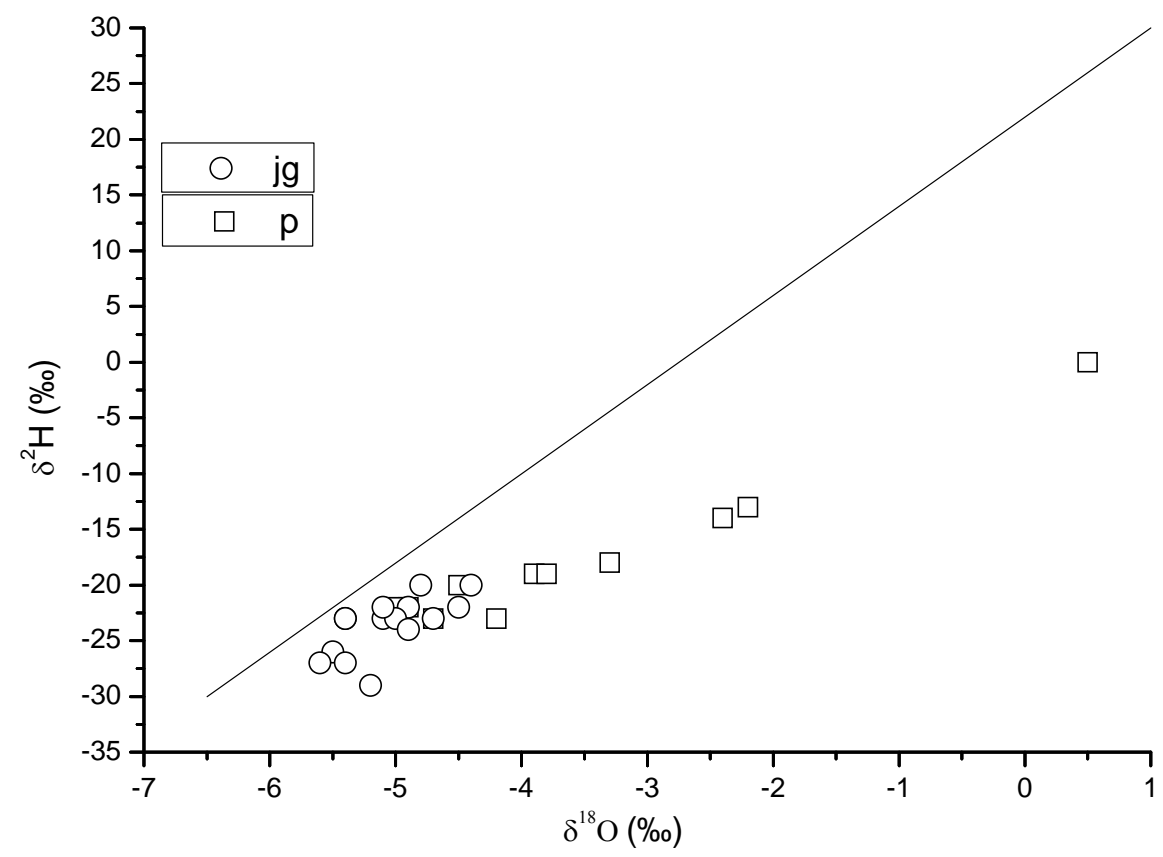

Figure $5 \delta^{2} \mathrm{H}-\delta^{18} \mathrm{O}$ diagram of wells is the Judea Group (jg) and Pleistocene (p) aquifers and the local meteoric line.

With the wells of the Pleistocene aquifer, the situation is more complicated. Several wells, which are very close to fishponds, show some contribution of significantly evaporated water derived from leakage from the ponds (samples 35, 35a, 35b, 39, 39a, 39b, and 50a in Table 3). When the wells exhibiting the marked evaporation are excluded from the data set, the isotope composition of the water in the remaining wells is similar to that characteristic of the water in the Coastal aquifer of Israel (Bruce et al. 2007). In Figure 5, this remaining data is shown and it is seen that the water of the Coastal aquifer has also undergone some evaporation during recharge, but the data is much less uniform than that of the Judea Group aquifer. Table 3 presents data from 25 wells, of which 7 were sampled more than once. Excluding wells with a significantly evaporated recharge and the well contaminated by fertilizers (see below), there are 2 wells (31 and 33) that were sampled both in the winter and in the summer. Their stable isotopes likewise show no variation between the seasons.

Figure 6 shows the data of the fishponds and of the wells affected by them. It is evident that there are 2 modes of operation of the fishponds: in one case the pond water is completely replaced periodically (28, 41, 42, 43, 44, and 45 in Table 3 ) and in the other case only the loss of water by evaporation and infiltration is replenished $(48,48 \mathrm{a}, 48 \mathrm{~b}, 48 \mathrm{c}, 49$, and 50 in Table 3). The partial recharge data of wells from the fishponds leakage is evident in Figure 6. The $\delta^{18} \mathrm{O}$ of sample 47 is the most positive (Table 3) and indicates extreme evaporation. Indeed, this pond is an evaporation pond for the production of salt. 


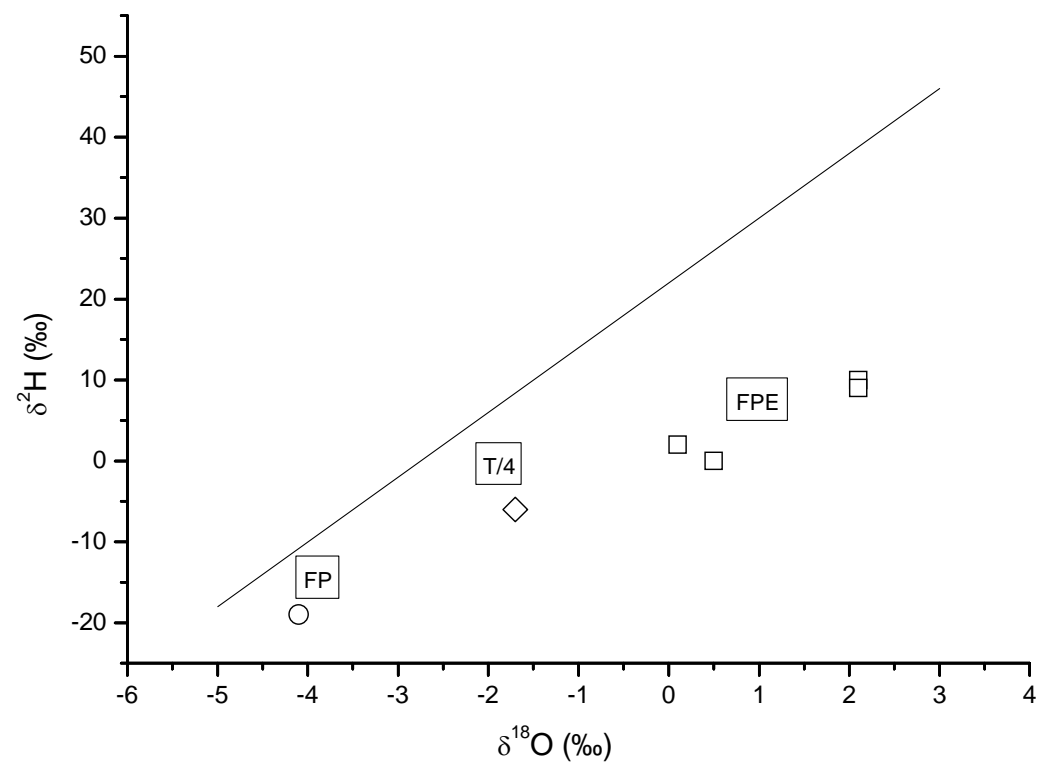

Figure $6 \delta^{2} \mathrm{H}-\delta^{18} \mathrm{O}$ diagram of fishponds and of the wells affected by them, and the local meteoric line. FP, T/4, and FPE are samples 48a, 50a, and 42 in Table 3.

\section{Tritium Data}

The input of tritium into the aquifer is via the rains. At the time of this study, rainfall generally contained between 3-5 TU (Table 1). The tritium concentrations in rains before 1953 were quite low and would have decayed significantly by the 1990s to quite low levels. In the Judea Group aquifer, tritium concentrations similar to the rain are seen uphill from the plain, in the phreatic section of the aquifer as denoted in the Nahal Oren wells and in the En Alon spring (samples 5c, 6c, and 16a, respectively, Table 2). But for these, the tritium concentrations in this aquifer are lower and may suggest a component that had undergone radioactive decay of tritium from "pre-bomb" rain. In the Pleistocene aquifer, $42 \%$ of the tritium results suggest fresh rains and the rest suggest older waters. Two results (36b and 36c, Table 3) area discounted because they are contaminated by fertilizers (see next section).

\section{$\delta^{13} \mathrm{C}$ Data}

In the Judea Group waters, $\delta^{13} \mathrm{C}$ ranges from $-10 \%$ to $-13 \%$ (Table 2). These results are similar to those of the Judea Group aquifer of the Samaria hills (Kroitoru 1987). The $\delta^{13} \mathrm{C}$ value of $-12.2 \%$ to $-12.8 \%$ seen in the En Alon and En Kedem springs (Figure 1, Table 2) is expected in groundwater from marine carbonate-rich $\left(\delta^{13} \mathrm{C}=\sim 0\right)$ terrain covered by $\mathrm{C}_{3}$ plants $\left(\delta^{13} \mathrm{C}=\sim-25 \%\right.$ o $)$ in the recharge region (Vogel et al. 1986), and dissolution of $\mathrm{CO}_{2}$ in equal proportions from the marine carbonate and the soil gas.

The values become slightly more positive as the water flows westward. This cannot be due to waterrock interaction by addition of the heavier ${ }^{13} \mathrm{C}$ isotope from the marine carbonate $\left(\delta^{13} \mathrm{C}= \pm 0\right)$; Gonfiatini and Zuppi (2003) have shown that in carbonate aquifers, isotope exchange occurs quite slowly, being noticeable only after thousands of years. This cannot be the case for these younger waters. 
The Pleistocene aquifer is also rich in shell material and is covered by $\mathrm{C}_{3}$ type plants. The $\delta^{13} \mathrm{C}$ values in it are more positive than would be expected from recharge similar to the Judea Group aquifer, but in many cases they are similar to the Coastal aquifer of Israel, where the range of $\delta^{13} \mathrm{C}$ is -9.5 to $-13.1 \%$ o (Bruce et al. 2007). The $\delta^{13} \mathrm{C}$ in many of the wells of the local Pleistocene aquifer of the Carmel coast are within this range; however, there are several wells that have $\delta^{13} \mathrm{C}$ values that are even more positive than this range (Table 3). Clearly, the Pleistocene aquifer water had undergone a significant evaporation (Figure 5). This may be due to infiltration of evaporated water from the fishponds into the aquifer. The “evaporated” $\delta^{13} \mathrm{C}$ values are not distributed uniformly throughout the aquifer. The most positive values, outside of the fishpond water themselves, are obtained from the wells closest to the fishponds. The wells that are further from the fishpond are more depleted, with values similar to those of the carbonate aquifer water.

In the water of some fishponds overlying the aquifer, there is a large enrichment in ${ }^{13} \mathrm{C}$ due to evaporation (Figure 6) (e.g samples 48, 48a, 48b, 48c, 49, and 50 in Table 3). The relatively high pH and temperature in the fishponds supersaturates calcite, and it is assumed then that carbonate heavy in ${ }^{13} \mathrm{C}$ is precipitating. The fishpond water then leaks downwards into the aquifer water and this enrichment in ${ }^{13} \mathrm{C}$ is observed in wells close to the fishponds (e.g. samples 35, 35a, 35b, 39, 39a, 39b, and 50a in Table 3), relative to water from wells located far from the fishponds (e.g. samples 31, 36, 38 in Table 3).

\section{Contamination by Fertilizers}

The addition of fertilizers (e.g. urea), which lack ${ }^{14} \mathrm{C}$, dilutes the total dissolved inorganic carbon reservoir in ${ }^{14} \mathrm{C}$. A value of only 23 pMC was measured at the kibbutz Nachsholim C (36b, Table 3) on 21 June 1994. At first glance, this would suggest that the water in the well is anomalously old compared to the average pMC values of the Pleistocene aquifer. The following year the well was remeasured; its ${ }^{14} \mathrm{C}$ activity rose to $49.3 \mathrm{pMC}$ (36c, Table 3), which is almost up to the activity of the other wells in the Pleistocene aquifer. The first measurement was not an analytical mistake for many other anomalous parameters were also encountered. A very high transient concentration of nitrate $(730 \mathrm{mg} / \mathrm{L})$ and of ammonia $(580 \mathrm{mg}(\mathrm{N}) / \mathrm{L})$ was noted at this time in the groundwater, compared to $25 \mathrm{mg} / \mathrm{L}$ of nitrates in the same well in 1995.

The fertilizer system is located in the well yard and it is believed that the first sample reflects leakage from it. The fertilizers, which are produced from a petroleum base at the Haifa Petrochemical Complex, contain "dead carbon" $\left({ }^{14} \mathrm{C}=0 \mathrm{pMC}\right.$ and $\delta^{13} \mathrm{C} \sim-25 \%$ ). It is possible that this "dead carbon" leaked into the aquifer and then mixed with the total dissolved carbon of the aquifer water. Because the contamination took place close to the water well, the sample contained very large proportions of the contaminant. Using a value of $50 \mathrm{pMC}$ for the aquifer, it is estimated that, close to the well, the fertilizers contributed more than $50 \%$ to the "environmental" ${ }^{14} \mathrm{C}$. This can be taken as an example of contamination resulting from agriculture that is carried out over much of the aquifer. In this particular case, we witnessed a large amount of fertilizer introduced as a point source, whereas in practice it is spread thinly over the terrain.

\section{Discussion of the Apparent Radiocarbon Ages}

The dating of groundwater with ${ }^{14} \mathrm{C}$ was first suggested by Münnich (1957). ${ }^{14} \mathrm{C}$ is produced in the upper atmosphere and is rapidly oxidized. The ${ }^{14} \mathrm{CO}_{2}$ mixes with the atmospheric $\mathrm{CO}_{2}$ reservoir. Once $\mathrm{CO}_{2}$-containing ${ }^{14} \mathrm{C}$ enters the groundwater, it decays at a known rate, related to its radioactive half-life of $5730 \mathrm{yr}$. Therefore, the age of the water $t$ can be formally related to the specific activity per mass of the water sampled, $A$, and the specific activity of the ${ }^{14} \mathrm{C}$ at the time when it first entered 
the groundwater, $A_{0}$, by the equation $t=-8270 \ln \left(A / A_{0}\right)$. It was not attempted to calculate $A_{0}$ of the water in the 2 aquifers by using the NETPATH code (Plummer et al. 1991) because of the problems inherent with estimating $A_{0}$ for modern water (Bouhlassa and Aiacchi 2002).

It can be seen (Tables 2, 3) that the Pleistocene and the Judea Group aquifers define 2 different clusters of ${ }^{14} \mathrm{C}$ values. The Pleistocene aquifer water has ${ }^{14} \mathrm{C}$ values below $55 \mathrm{pMC}$ (the Shfeya A well, 38 in Table 3, is a mixture with the Judea Group). The Judea Group wells have ${ }^{14} \mathrm{C}$ concentrations of $65 \mathrm{pMC}$ and greater. The 10-pMC difference between the 2 aquifers would imply that the water in the Pleistocene aquifer is at least 1000 yr older than the water in the Judea Group. This would seem to contradict the determinations that found similarity between the aquifers in their hydraulic parameters. It would also contradict the Darcy calculations that would not allow for ages of water to be a few tens of years, which is reasonable.

The major factor that must be considered when calculating the ${ }^{14} \mathrm{C}$ age of water is the value of the initial ${ }^{14} \mathrm{C}$ introduced into the aquifer, $A_{0}$, that is used in the age equation. Recently, a correction factor has been determined for the Judea Group aquifer and for the Pleistocene aquifer (Carmi 2007; Carmi et al. 2004, 2009), which accounts for the interactions that transpire between the recharge water, the soil-gas and the solid phase within the unsaturated zone. The corrected activities are 0.62 and 0.54 of the atmospheric values at the time of deposition of rain on the ground for the Judea Group and the Pleistocene aquifers, respectively. From this, it is possible to estimate the atmospheric ${ }^{14} \mathrm{C}$ at the time of recharge. In the Judea Group aquifer (Table 2), the ${ }^{14} \mathrm{C}$ activity of the wells suggests a prethermonuclear or very early thermonuclear deposition of the rain. For sample 23d (Taninim spring, Table 2), the atmospheric value is 62.2/0.62 = 100.3 pMC; for sample 10c (Hof Carmel 7, Table 2), it is 64.9/0.62 = 104.6 pMC; and for sample 26 (Atlit council, Table 2), it is 65.4/ $0.62=105.5 \mathrm{pMC}$. The Taninim spring result seems to be from the beginning of the thermonuclear pulse (Levin and Kromer 2004). The possibility that the Hof Carmel and Atlit council values represent the end of the atmospheric ${ }^{14} \mathrm{C}$ pulse can be discounted because this would imply an extremely fast flow of water. Thus, it seems that the Judea aquifer results represent the very beginning of the thermonuclear pulse. The data of En Alon spring (Table 2) suggests a short circuit in the aquifer, with immature water. In the Pleistocene aquifer, samples 36b and 36c (Table 3) are discounted because they represent contamination by urea and its gradual removal by water flow. For the Newe Yam 3 and 5 (samples 31b and 33b in Table 3), the calculation gives atmospheric values of 53.2/ $0.54=98.5$ and $54.9 / 0.54=101.7 \mathrm{pMC}$, respectively. The indication is that these results are from the very beginning of the ascent of the thermonuclear pulse. It suggests input by freshwater from approximately 2-3 decades prior. Thus, it can be seen that the difference in ages between the 2 aquifers is only a few decades and not the millennium result calculated from the decay equation. The agreement between the estimates of the Darcy and ${ }^{14} \mathrm{C}$ calculations is now seen to be quite good.

\section{CONCLUSIONS}

The assumption that 2 geographical close aquifers situated in close geographical proximity should have similar initial ${ }^{14} \mathrm{C}$ values is seen to be unjustified. Each aquiferal type may lead to specific isotopic fractions during water percolation through the unsaturated zone to the water table. When the correct isotopic fractionation factors are known and are employed, good agreement can be obtained both in absolute age calculations using ${ }^{14} \mathrm{C}$ between aquifers, as well as with flow rates calculated using the Darcy equation. The 2 aquifers are extensively utilized, and this is seen by the input from fishponds into adjacent wells and by contamination of one well by fertilizers. 


\section{REFERENCES}

Ball JW, Nordstrom DK. 1992. User's manual for WATEQ4F, with revised thermodynamic data base and test cases for calculating speciation of major, trace, and redox elements in natural waters. US Geological Survey. Revised and reprinted Open-File Report 91-183.

Bouhlassa S, Aiachi A. 2002. Groundwater dating with radiocarbon: application to an aquifer under semi-arid conditions in the south of Morocco (Guelmime). Applied Radiation and Isotopes 56(4):637-47.

Bruce DL, Yechieli Y, Zilberbrand M, Kaufman A, Friedman GM. 2007. Delineation of the Coastal Aquifer of Israel based on repetitive analyses of radiocarbon and tritium. Journal of Hydrology 343(1-2):56-70.

Carmi I. 2007. Processes that affect the isotopic concentration of carbon in the unsaturated zone: implications for the improved dating of groundwater with ${ }^{14} \mathrm{C}[\mathrm{PhD}$ thesis]. Tel-Aviv University. $66 \mathrm{p}$.

Carmi I, Kronfeld J, Yechieli Y, Boaretto E, BarMathews M, Ayalon A. 2004. A direct estimate of the initial concentration of ${ }^{14} \mathrm{C}$ in the mountain aquifer of Israel. Radiocarbon 46(2):497-500.

Carmi I, Kronfeld J, Yechieli Y, Yakir D, Boaretto E, Stiller M. 2009. Carbon isotopes in pore water of the unsaturated zone and their relevance for initial ${ }^{14} \mathrm{C}$ activity in groundwater in the coastal aquifer of Israel. Chemical Geology 268(3-4):189-96.

Coplen TB. 1996. New guidelines for reporting stable hydrogen, carbon and oxygen isotope-ratio data. Geochemica et Cosmochimica Acta 60(17):3359-60.
Craig H. 1953. The geochemistry of the stable carbon isotopes. Geochimica et Cosmochimica Acta 3:53-92.

Gat JR, Dansgaard W. 1972. Stable isotopes survey of fresh water occurrences in Israel and the northern Jordan Rift Valley. Journal of Hydrology 16(3):177-211.

Gonfiantini R, Zuppi GM. 2003. Carbon isotope exchange rate of DIC in karst groundwater. Chemical Geology 197(1-4):319-36.

Guttman J. 1999. Defining flow systems and groundwater interactions in the multi-aquifer system of the Carmel coast region [PhD thesis]. Tel-Aviv University. $65 \mathrm{p}$.

Kroitoru L. 1987. The characterization of flow systems in carbonate rocks defined by the groundwater parameters-central Israel [PhD thesis]. Weizmann Institute of Science. $124 \mathrm{p}$.

Levin I, Kromer B. 2004. The tropospheric ${ }^{14} \mathrm{CO}_{2}$ levels in mid-latitudes of the Northern Hemisphere. Radiocarbon 46(3):1261-72.

Münnich KO. 1957. Messung des ${ }^{14} \mathrm{C}$-Gehaltes von hartem Grundwasserr. Naturwissenschaften 44:32-4.

Plummer NL, Prestemon EC, Parkhurst DL. 1994. An interactive code (NETPATH) for modeling net geochemical reaction along a flow path, version 2.0. US Geological Survey Water Resources Investigations Report 94-4169. Reston: USGS.

Vogel JC, Fuls A, Danin A. 1986. Geographical and environmental distributions of $\mathrm{C}_{3}$ and $\mathrm{C}_{4}$ plants in the Sinai, Negev and Judean deserts. Oecologia 70(2):25865. 